\title{
Production of Biomass-Degrading Enzymes by Trichoderma reesei Using Liquid Hot Water-Pretreated Corncob in Different Conditions of Oxygen Transfer
}

\author{
Michele Michelin $^{1}$ (1) - André M. O. Mota ${ }^{1} \cdot$ Daniel P. Silva $^{2} \cdot$ Denise S. Ruzene ${ }^{2} \cdot$ António A. Vicente $^{1} \cdot$ José A. Teixeira ${ }^{1}$
}

Published online: 8 June 2019

(C) Springer Science+Business Media, LLC, part of Springer Nature 2019

\begin{abstract}
Enzymatic hydrolysis accounts for $20 \%$ of the total cost in the conversion process of lignocellulosic biomass into bioethanol. Therefore, production of biomass-degrading enzymes by using lignocellulosic residue as a fermentation substrate may be an alternative to decrease the production costs. In this study, corncob (CC) has been pretreated by liquid hot water (LHW) at $200^{\circ} \mathrm{C}$ for $30 \mathrm{~min}$ and used as inducer source for production of biomass-degrading enzymes by Trichoderma reesei MUM 97.53. The pretreatment was used to increase the cellulose content and the accessibility to lignocellulosic material. Although the filamentous fungus secreted a broad range of cellulolytic and hemicellulolytic enzymes when grown on untreated CC, higher enzyme productions were obtained when cultured on LHW-pretreated CC in a 2-L stirred tank bioreactor (STB). Besides, the effects of aeration ( 2 and $4 \mathrm{vvm}$ ) and agitation (150 and $250 \mathrm{rpm}$ ) rates on enzyme production were studied by submerged fermentation in a batch STB and correlated with the volumetric oxygen transfer coefficient $\left(k_{L} a\right)$. Maximal cellulase, xylanase, and $\beta$ xylosidase productions were found at $150 \mathrm{rpm}$ and $4 \mathrm{vvm}$, while the highest $\beta$-glucosidase levels were obtained at $150 \mathrm{rpm}$ and $2 \mathrm{vvm}$, that corresponded to $k_{L} a$ values of $32.50 \mathrm{~h}^{-1}$ and $16.41 \mathrm{~h}^{-1}$, respectively. At higher agitation, a lower enzymatic production was observed probably due to the high shear stress in the fungal hyphae.
\end{abstract}

Keywords Cellulases $\cdot$ Xylanases $\cdot$ Trichoderma $\cdot$ Autohydrolysis $\cdot$ Bioreactor $\cdot k_{L} a$

\section{Introduction}

Biomass-degrading enzymes are one of the greatest challenges in the use of the biochemical route for lignocellulosic biomass conversion into add-value bioproducts. This is mainly due to the high production cost of the enzymes, the low yields, and the considerable quantities of enzymes that are required during the process. For example, in the bioethanol production, the enzyme cost represents about $15-28 \%$ of the bioethanol selling price, or $20 \%$ of the overall bioethanol production costs [1]. Additionally, it has been reported that the biggest cost in the cellulase production is in the raw materials and consumables and that this cost varies according to the production approach, being the integrated

Michele Michelin

mimichelin.bio@gmail.com

1 CEB - Centre of Biological Engineering, University of Minho, 4710-057 Braga, Portugal

2 Núcleo de Engenharia de Produção, Universidade Federal de Sergipe, Aracaju, SE 49100-000, Brazil method, where the cellulose is used as raw material to produce the cellulase, the most cost-effective compared to others that use glucose as raw material [2].

Thus, recent studies have focused on the improvement of the fermentation processes for microbial enzyme production, as well as in the development of hyper-producing microbial strains, in order to reduce the costs and make the process economically viable [3-5]. Other possibility is the use of lignocellulosic biomass as a inducer source for the production of enzymes. In fact, lignocellulosic biomass has been considered a promising material for production of these enzymes because of its abundance, low cost and wide availability [6]. Besides, it has been shown that better performances are obtained when an enzyme complex is prepared from the same lignocellulosic material that is meant to be hydrolyzed by that complex [7-9].

Various types of lignocellulosic biomass, such as hardwood, bagasse, and straws, have been studied as inducer sources or fermentation substrate to improve the lignocellulosic enzyme production $[10,11]$. One of the ways to improve the production is to use pretreated biomass which can lead to an improvement in production and yield since the pretreatment breaks the lignocellulosic structure and makes cellulose 
and hemicellulose more accessible for the fermenting microorganisms [7, 8]. Hydrothermal pretreatment, such as liquid hot water (LHW), has been considered a suitable and costeffective pretreatment for biomass fractionation. It depolimerizes the hemicellulose and a small portion of lignin into the hydrolysates, while it recovers a more accessible cellulose-lignin fraction. Additionally, this pretreatment presents some advantages compared to other pretreatment technologies, like simple and economical operation, limited equipment corrosion problems, reduced polysaccharide losses, and inhibitor formation; does not require the addition and recovery of chemicals different from water; and is considered an environmentally friendly process [12]. Many researchers have used lignocellulosic hydrolysates and pretreated solids for enzyme production and have showed that these pretreated materials improve enzyme production [11-16].

Cellulases and hemicellulases are produced by a wide variety of microorganisms, such as bacteria and fungi. However, filamentous fungi are known by their ability to secrete large amounts of protein, among which, enzymes. Most commercial cellulases and hemicellulases are produced by submerged cultivation using filamentous fungi of the genera Trichoderma and Aspergillus [17]. These aerobic microorganisms require good oxygen transfer, which is related to the aeration and agitation rates, to achieve good growth and subsequent enzyme production. However, the shear stress caused by the stirred tank bioreactor (STB) turbine, as a result of agitation intensity, on mycelia causes a negative impact on growth and enzyme production $[18,19]$. This calls for the optimization of the fermentation conditions. Other authors have studied the interactive influence of aeration and agitation rates on the volumetric oxygen transfer coefficient $\left(k_{L} a\right)$ to improve the production of several bioproducts, together with the negative impact of shear forces on microorganism and bioproduct production [20-24].

The current study describes the effects of aeration and agitation rates in a lab-scale stirred tank bioreactor (STB) on the production of biomass-degrading enzymes, namely cellulase, $\beta$-glucosidase, xylanase, and $\beta$-xylosidase, by a selected strain of Trichodema reesei MUM 97.53 cultivated under batch fermentation, using corncob pretreated by liquid hot water (LHW) at $200^{\circ} \mathrm{C}$ for $30 \mathrm{~min}$ as substrate.

\section{Materials and Methods}

\section{Material}

Corncob (CC) was kindly supplied by a local farmer (Caíde de Rei, Lousada, Northern Portugal). The material was dried at $40^{\circ} \mathrm{C}$ for $12 \mathrm{~h}$. After that, it was cut into small chips $(1-3 \mathrm{~cm})$, milled and sieved on particle sizes of $1 \mathrm{~mm}$, and stored at room temperature.

\section{Chemical Composition}

The chemical composition of untreated and pretreated $\mathrm{CC}$ was determined according to the standard Laboratory Analytical Procedures (LAPs) for biomass analysis provided by the US National Renewable Energy Laboratory (NREL) [25]. The analyzed components were glucan, xylan, arabinan, acetyl gropus, lignin, and ash.

Glucose, xylose, arabionose, and acetic acid were analyzed by high-performance liquid chromatography (HPLC) in a Jasco chromatograph + sampler (JASCO Intelligent Sampler AS 2057 Plus) with a refractive index (RI) detector, using a Metacarb $87 \mathrm{H}$ column $(300 \times 7.8 \mathrm{~mm}$, Varian, USA $)$ preheated at $60{ }^{\circ} \mathrm{C}$. The mobile phase $\left(0.005 \mathrm{~mol} \mathrm{~L}^{-1}\right.$ $\mathrm{H}_{2} \mathrm{SO}_{4}$ in Milli-Q water) was filtered through $0.2 \mu \mathrm{m}$ Millipore ${ }^{\circledR}$ nylon filter and degassed. The flow rate was $0.7 \mathrm{~mL} \mathrm{~min}^{-1}$. All measurements were made in duplicate.

\section{Liquid Hot Water Pretreatment}

LHW pretreatment was carried out in a $160-\mathrm{mL}$ stainless steel cylinder reactor $(4.0 \times 12.4 \mathrm{~cm})$, with working volume of $50 \mathrm{~mL}$. Milled CC samples and water were mixed in order to obtain $10 \%(w / v)$ solid loading. The reactor was submerged in an oil bath with an open heating circulator (Julabo Labortechnik GmbH, Seelbath, Germany) with PID temperature control at $200{ }^{\circ} \mathrm{C}$ for $30 \mathrm{~min}\left(\log \left(R_{0}\right)\right.$ of 4.42). After that, the reactor was immediately cooled in an ice bath to quench the reaction. The insoluble solids were separated from the liquid fraction by vacuum filtration (filter paper) and used as substrate for fermentation.

\section{Microbial Strain}

Tricoderma reesei MUM 97.53 was kindly provided by MUM (Micoteca da Universidade do Minho, Portugal), that is a member of the European Culture Collections Organization (ECCO) and the World Federation for Culture Collections (WFCC) and is also registered in the WDCM (World Data Centre of Microorganisms) with the number 816. Fungus stock cultures were propagated on PDA medium plates at $30{ }^{\circ} \mathrm{C}$ for 1 week. Thereafter, the plates were stored at $4{ }^{\circ} \mathrm{C}$ until use.

\section{Medium and Inoculum Preparation}

The microorganism was grown in 500-mL Erlenmeyer flasks, containing 125-mL Mandels medium [26], and 1\% $(w / v)$ unwashed slurry of CC solids recovered after LHW pretreatment, as inducer source of biomass-degrading enzymes. After autoclaving, the flasks were inoculated with a spore suspension, containing $2.5 \times 10^{10}$ spores $\mathrm{mL}^{-1}$, determined in a Neubauer counting chamber, and incubated on a rotatory 
shaker at $30{ }^{\circ} \mathrm{C}, 100 \mathrm{rpm}$, for $72 \mathrm{~h}$. After that, this culture was used to determine the studied enzyme activities and as pregrowth culture to start the bioreactor fermentation. Untreated $\mathrm{CC}$ was also used in shake flask fermentation at the same conditions described above.

\section{Bioreactor Configuration and Operating Conditions}

Enzyme production was carried out in a lab scale 2 L STB (Bioengineering AG CH-8636, Wald, Switzerland) with 1.25 L working volume, equipped with two 6-bladed Rushton turbines and automatic monitoring and control facilities for temperature, $\mathrm{pH}$, aeration, and agitation rates.

Batch fermentations in the STB were initiated with an inoculum of $10 \%(\mathrm{v} / \mathrm{v})$ of the bioreactor volume of a $T$. reesei MUM 97.53 culture that was pre-grown at $30{ }^{\circ} \mathrm{C}$ for $72 \mathrm{~h}$. STB containing Mandels medium, $\mathrm{pH} 5.4 \pm 0.2$, and $1 \%(w / v)$ unwashed slurry of CC solids recovered after LHW pretreatment was operated to optimize aeration and agitation rates for the production of biomass-degrading enzymes. Two levels of airflow rates ( 2 and $4 \mathrm{vvm}$ ) were studied, and at each airflow rate, two different agitation rates (150 and $250 \mathrm{rpm})$ were tested; the fermentation was performed at $30{ }^{\circ} \mathrm{C}$ for 10 days (Fig. 1).
Dissolved oxygen (DO) and $\mathrm{pH}$ probes (Mettler-Toledo, Columbus, Ohio, EUA) were used to monitor the DO and the $\mathrm{pH}$, respectively. One milliliter of antifoam 204 (SigmaAldrich, St. Louis, MO, USA) was used at the beginning of fermentation. Estimation of enzyme production was carried out at every $24 \mathrm{~h}$ interval.

\section{Enzymatic Assays}

Cellulase and xylanase activities were determined by measuring the released reducing sugars by the 3,5-dinitrosalicylic acid (DNS) method [27], using glucose or xylose, respectively, as standard. The cellulase (endo- and exo-glucanase) assay was performed at $55{ }^{\circ} \mathrm{C}$ for $30 \mathrm{~min}$, using Whatman No. 1 filter paper as substrate $(10 \mathrm{~mm} \times 30 \mathrm{~mm})$ in $0.05 \mathrm{M}$ sodium citrate buffer, $\mathrm{pH} 4.8$, according to [28], and expressed as Filter Paper Unit per milliliter (FPU/mL). The xylanase assay was performed at $60^{\circ} \mathrm{C}$ for $20 \mathrm{~min}$, using $1 \%(\mathrm{w} / \mathrm{v})$ birchwood xylan (Sigma-Aldrich, St. Louis, MO, USA) in citratephosphate buffer, $\mathrm{pH}$ 6.0, as substrate, according to [19], and expressed as International Unit per milliliter (IU/mL).

The $\beta$-glucosidase assay was performed at $50{ }^{\circ} \mathrm{C}$ for $10 \mathrm{~min}$, by monitoring the hydrolysis of $5 \mathrm{mmol} \mathrm{L}^{-1} \rho$ nitrophenol- $\beta$-D-glucopyranoside (PNP-glu) in $0.05 \mathrm{M}$ sodium citrate buffer, $\mathrm{pH} 4.8$, while the $\beta$-xylosidase assay was
Fig. 1 The overall scheme of the fermentation process. A.

Pretreatment step. B.

Fermentation step in a 2 L STB.

Diagram of stirred tank: $d_{\mathrm{b}}$, bioreactor diameter $(9.5 \mathrm{~cm}) ; h_{\mathrm{b}}$, bioreactor height $(30 \mathrm{~cm}) ; d_{\mathrm{i}}$, impeller diameter $(4 \mathrm{~cm}) ; h_{\mathrm{i}}$, distance between impellers $(5.5 \mathrm{~cm})$; $h_{\mathrm{i}-\mathrm{b}}$, distance between the impeller and the bottom of the reactor $(5 \mathrm{~cm})$

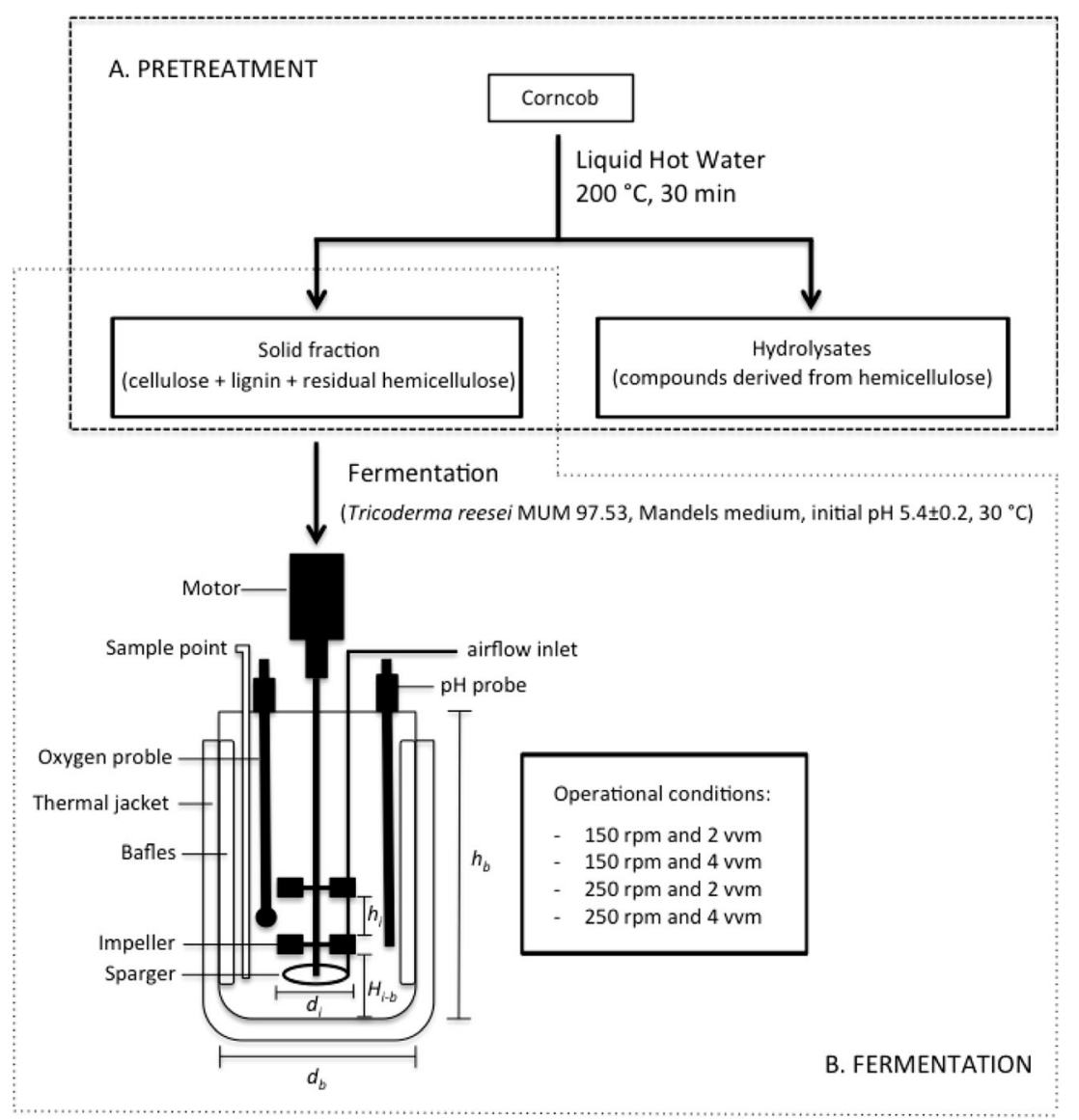


performed at $70{ }^{\circ} \mathrm{C}$ for $15 \mathrm{~min}$, using $5 \mathrm{mmol} \mathrm{L}{ }^{-1} \rho$ nitrophenol- $\beta$-D-xylopyranoside (PNP-xyl) in citratephosphate buffer, $\mathrm{pH} 4.5$, as substrate [19]. The released $\rho$ nitrophenolate of both assays was estimated with $1 \mathrm{~mol} \mathrm{~L}^{-1}$ sodium carbonate, using $\rho$-nitrophenol as standard. One international unit (IU) of enzymatic activity was defined as the amount of enzyme that releases $1 \mu \mathrm{mol}$ of product per minute under the assay conditions. All assays were performed in duplicate. The values presented correspond to mean values of replicate experiments.

\section{$k_{L} a$ Measurement}

The volumetric oxygen transfer coefficient $\left(k_{L} a\right)$ was measured at $30{ }^{\circ} \mathrm{C}$ in cell-free medium by the dynamic gassingout method [29]. This method was performed by sparging nitrogen until the dissolved oxygen (DO) concentration falls close to zero and then monitoring the DO concentration after the start of the humidified air injection into the bioreactor. At this moment, the oxygen transfer process to the medium begins and continues until DO in the liquid reaches the saturation. DO concentration values were measured on-line using an $\mathrm{O}_{2}$ electrode (CellOx 325, WTW) and recorded through a data acquisition board. Two measurements were done for each condition. The influence of oxygen electrode on $k_{L} a$ was considered negligible due to the low probe response time (6s), which was significantly lower than $1 / k_{L} a$, corresponding to an experimental error lower than $6 \%$.

The variation on DO concentration with time, $t$, was recorded, and $k_{L} a$ values were calculated according to the equation:

$\ln \left(\mathrm{C}^{*-} \mathrm{C}\right)=\ln \left(\mathrm{C}^{*-} \mathrm{C} 0\right)-k_{L} a . \mathrm{t}$

where $C^{*}$ and $C$ are, respectively, the saturation concentration of oxygen and oxygen concentration in the liquid. Assuming the liquid phase as homogeneous and being $C 0$ the concentration of oxygen at $t=0$, the $k_{L} a$ was determined by plotting $\ln \left(C^{*}-C\right)$ against time $(t)$ using MATLAB (MathWorks, Natick, MA, USA), version 7.2.0.232 (R2006a).

\section{Results and Discussion}

\section{Influence of the Biomass Pretreatment in Enzyme Production}

$\mathrm{CC}$ was pretreated by LHW at $200{ }^{\circ} \mathrm{C}$ for $30 \mathrm{~min}$, and the recovered unwashed slurry of $\mathrm{CC}$ solids was used as fermentation substrate for the production of cellulases and xylanases in shake flasks. This pretreatment condition was selected based on a previous work that investigated several conditions of LHW pretreatment [30]. Untreated CC contained approx. $38.0 \%$ cellulose and $31.5 \%$ hemicellulose. Once the LHW pretreatment removes mainly the hemicellulose from lignocellulosic biomass, the cellulose content of pretreated CC increased to $60.5 \%$ and the hemicellulose content was reduced to $13.4 \%$, of which $10.7 \%$ is xylan (Table 1 ). Liquid fraction contained $22 \mathrm{~g} / \mathrm{L}$ of xylooligossacarides [30]. Part of the hemicellulose contained in the solid fraction may be free hemicellulose that was removed in the pretreatment process but remained impregned in the solids after the drying process, since the solids were not washed after the pretreatment. Unwashed solids were used as substrate in the fermentation since this hemicellulose could be advantageous for the xylanase production.

Figure 2 presents the enzyme production obtained by Trichoderma reesei MUM 97.53 after 72 h of fermentation, using untreated and pretreated CC. The cellulase (FP activity) and $\beta$-glucosidase productions were, respectively, $18.4 \%$ and $47.9 \%$ higher on pretreated CC than on untreated CC. This influence is explained by the effect of the hydrothermal pretreatment on $\mathrm{CC}$, which provokes the disruption of the structure of the lignocellulosic matrix, and thus increases the availability of the lignocellulosic components and the accessibility of the microorganisms to it, after its fractionation by the pretreatment. Xylanase and $\beta$-xylosidase productions also increased when pretreated $\mathrm{CC}$ was used, achieving rates of $28.2 \%$ and $5.1 \%$, respectively, even with the removal of part of the hemicellulose from the solid fraction after the pretreatment. This may be associated with improved accessibility of the microorganism to the hemicellulose fraction due to disruption of the lignocellulosic matrix.

Cunha et al. [31] reported 64\% higher endoglucanase production in steam-explosion pretreated sugarcane bagasse (SCB) as substrate than in untreated $\mathrm{SCB}$, in sequential fermentation (SF). Those authors used a pre-culture initiated as solid state fermentation (SSF) under static conditions for $24 \mathrm{~h}$, which was continued by sequential submerged fermentation $(\mathrm{SmF})$ in an orbital shaker, with addition of an enriched nutrient medium for $48 \mathrm{~h}$, and finally used to initiate the enzyme production in the STB.

In the current work, $3.5 \mathrm{FPU} \mathrm{mL} \mathrm{m}^{-1}$ of cellulase and 3.8 $\mathrm{IU} \mathrm{mL} \mathrm{m}^{-1}$ of $\beta$-glucosidase were achieved after $72 \mathrm{~h}$ with the

Table 1 Composition of untreated and pretreated corncob by liquid hot water at $200{ }^{\circ} \mathrm{C}$ for $30 \mathrm{~min}$

\begin{tabular}{lll}
\hline Components & Corncob (\%) & Pretreated corncob (\%) \\
\hline Cellulose & $37.95 \pm 1.81$ & $60.55 \pm 3.84$ \\
Hemicellulose & $31.52 \pm 2.09$ & $13.40 \pm 1.77$ \\
Lignin & $19.09 \pm 0.21$ & $20.56 \pm 0.08$ \\
Ash & $0.77 \pm 0.07$ & $0.34 \pm 0.02$ \\
Moisture & 6.86 & 5.06 \\
\hline
\end{tabular}


Fig. 2 Production of cellulase, $\beta$-glucosidase, xylanase, and

$\beta$-xylosidase in untreated corncob (black column) and LHWpretreated corncob (gray column) in shake flasks. The microorganism was cultivated at $30^{\circ} \mathrm{C}$, $100 \mathrm{rpm}$ during $72 \mathrm{~h}$

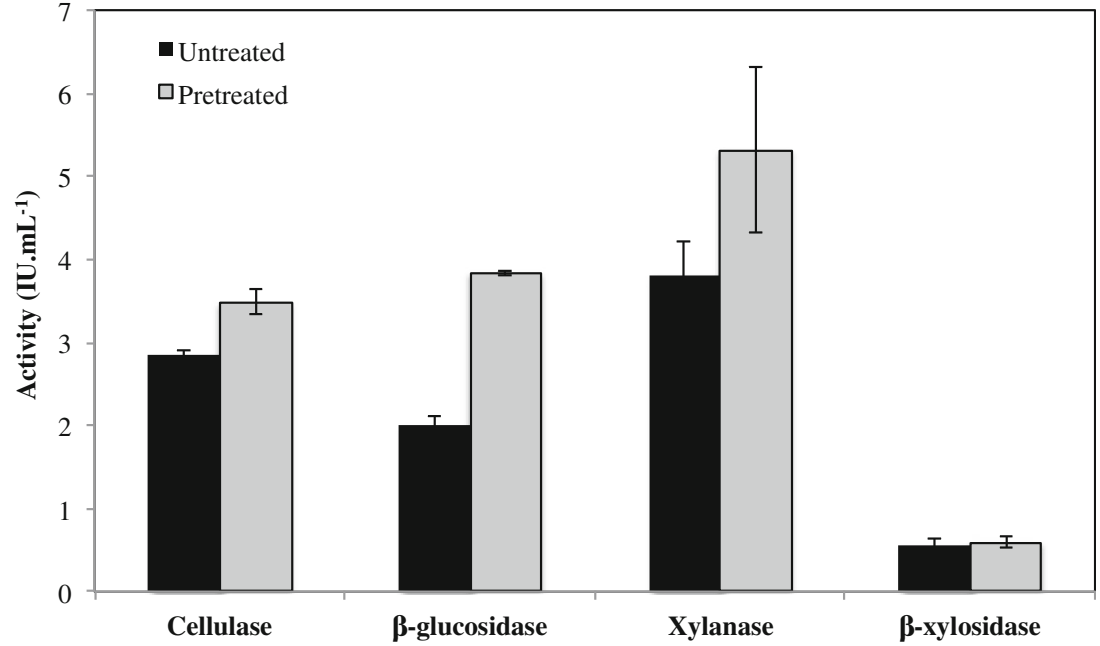

LHW-pretreated biomass on shake flasks. These production values are higher than those obtained by Gottschalk et al. [32] that achieved a cellulase production of $1.7 \mathrm{FPU} \mathrm{mL}^{-1}$ and 0.34 IU $\mathrm{mL}^{-1}$ of $\beta$-glucosidase on shake flasks culture of $T$. reese $i$ using $3 \%(w / v)$ lactose. However, the same authors also observed a lower FP activity (0.42 $\left.\mathrm{FPU} \mathrm{mL}^{-1}\right)$ and an improved $\beta$-glucosidase activity ( $45.6 \mathrm{IU} \mathrm{mL}^{-1}$ ) on shake flask culture of Aspergillus awamori using 3\% (w/v) wheat bran. These differences may be related with the inducer source, as well as with the fungal species.

In relation to xylanase production, a value of $5.3 \mathrm{IU} \mathrm{mL}^{-1}$ was achieved using pretreated CC. This production was lower than xylanase production reported in a previous work by Michelin et al. [16], where $14 \mathrm{IU} \mathrm{mL}^{-1}$ and $13.2 \mathrm{IU} \mathrm{mL}^{-1}$ were obtained in cultures of A. terricola and A. ochraceus, respectively, with a mixture of untreated $\mathrm{CC}$ and $\mathrm{CC}$ hydrolysates from LHW pretreatment. Gottschalk et al. [32] also studied the xylanase production by $T$. reesei and A. awamori cultures, and 12.6 and $79.1 \mathrm{IU} \mathrm{mL}^{-1}$, respectively, were obtained.

These results could be related with the fungal specie, since T. reesei is known to be an efficient fungus for production of cellulase. However, it has been described that $\beta$-glucosidase enzyme is produced in very small quantities by this microorganism [33]. On the other hand, xylanase production has been mainly studied in the Aspergillus species [15, 16, 19, 34-36].

The pretreatment, as well as the fungal specie, appears to have influenced enzyme production, and the higher enzyme levels obtained with the LHW-pretreated material were probably due to the increased accessibility of the microorganism to the lignocellulosic components due to the disruption of the lignocellulosic matrix caused by the pretreatment. Additionally, the absence or low content of inhibitory byproducts, characteristic of LHW pretreatment [37], associated with this improved accessibility may have favored the increase on enzyme production.

\section{Influence of Aeration and Agitation Rates in the Enzymatic Production}

In this work, batch fermentation was run on STB with the T. reesei MUM 97.53 fungus, and the influence of aeration and agitation rates on biomass-degrading enzyme production, by using LHW-pretreated CC, as fermentation substrate, were analyzed. Two different airflow rates, namely 2 and 4 vvm, were analyzed, and at each airflow rate, two agitation rates, i.e., 150 and $250 \mathrm{rpm}$, were tested.

Figure 3 shows the enzymatic production (cellulase, $\beta$-glucosidase, xylanase, $\beta$-xylosidase), and dissolved oxygen (DO) and $\mathrm{pH}$ behaviors during 10 days fermentation. The highest enzymatic levels were observed in the condition of lower agitation, being the best production achieved at $150 \mathrm{rpm}$ and $4 \mathrm{vvm}$ for cellulase (8.4 $\mathrm{FPU} \mathrm{m}^{-1}$ after 5 days fermentation; Fig. 3a), xylanase (11.1 $\mathrm{IU} \mathrm{ml}^{-1}$ after 3 days fermentation; Fig. 3c), and $\beta$-xylosidase (2.1 IU ml ${ }^{-1}$ after 2 days fermentation; Fig. 3d), while for the $\beta$-glucosidase activity (5.8 $\mathrm{IU} \mathrm{ml}^{-1}$ after 10 days fermentation; Fig. 3b), the best production was achieved at $150 \mathrm{rpm}$ and 2 vvm condition. In addition, $\beta$-glucosidase activities continued to show an upward trend after 10 days fermentation (Fig. 3b), suggesting that maximum values had not been reached. This late production can be associated with the complexity of the substrate, since $\beta$-glucosidase production occurs after the production of the endoglucanase, that cleaves the cellulolytic polymers randomly to produce new chain ends including cellobiose, that is a substrate for $\beta$-glucosidase [38]; this may explain that the reason for the $\beta$-glucosidase is still increasing after 10 days of fermentation. Similar results were observed by Reis et al. [39] and Li et al. [40] regarding this late $\beta$-glucosidase production.

Patel et al. [41] studied the growth of T. reesei RUT-C30 in different bioreactors and found that lower agitation rate resulted in higher FP activity, although higher agitation frequencies 

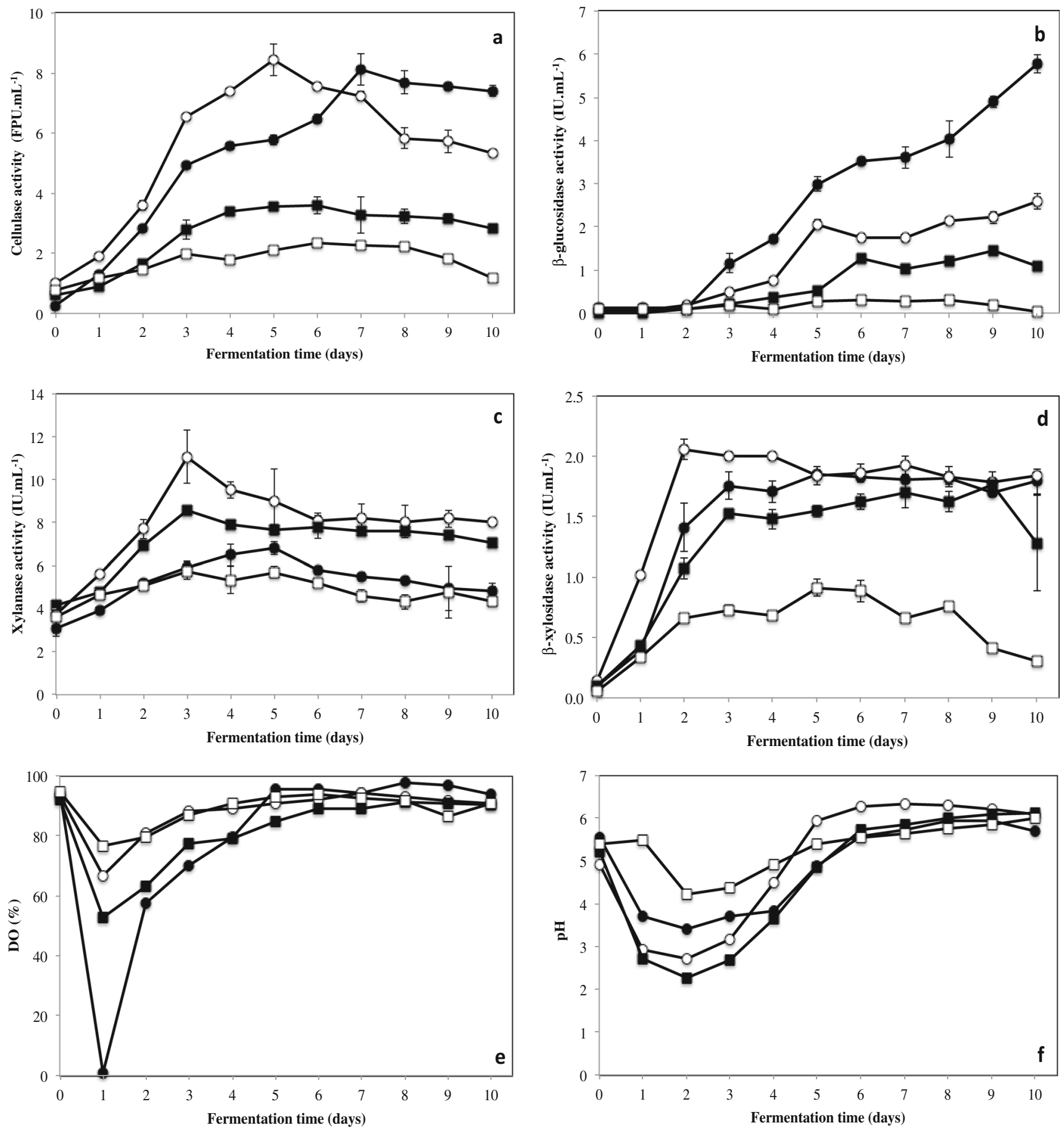

Fig. 3 Time course for cellulase activity (a), $\beta$-glucosidase activity (b), xylanase activity $(\mathbf{c}), \beta$-xylosidase activity $(\mathbf{d})$, dissolved oxygen $(\mathbf{e})$, and $\mathrm{pH}$ (f) in the stirred tank bioreactor at $150 \mathrm{rpm}$ and 2 vvm (black circle);

$150 \mathrm{rpm}$ and $4 \mathrm{vvm}$ (white circle); $250 \mathrm{rpm}$ and $2 \mathrm{vvm}$ (black square); and $250 \mathrm{rpm}$ and $4 \mathrm{vvm}$ (white square). The microorganism was cultivated at $30{ }^{\circ} \mathrm{C}$ during 10 days

increased the biomass, due to a better oxygen supply. The agitation rate and the airflow in cultures of filamentous fungi strongly influence the growth and production of extracellular enzymes [42]. In the current work, it was possible to improve enzyme production from 50 to $95 \%$, as in the case of $\beta$-glucosidase, by comparing the best conditions for each enzyme production with the worst studied conditions ( $250 \mathrm{rpm}, 4 \mathrm{vvm}$ ).

The lower enzyme production observed at $250 \mathrm{rpm}$ when compared to $150 \mathrm{rpm}$ can be related to the shearing effect of the STB turbines. In practice, it has been often reported that the shear stress imposed on mycelial microorganisms at vigorous agitations could lead to morphological and physiological changes, leading to a decrease in enzyme productivity [19, 20, 43]. In addition, the highest enzymatic activity (cellulase, xylanase, and 


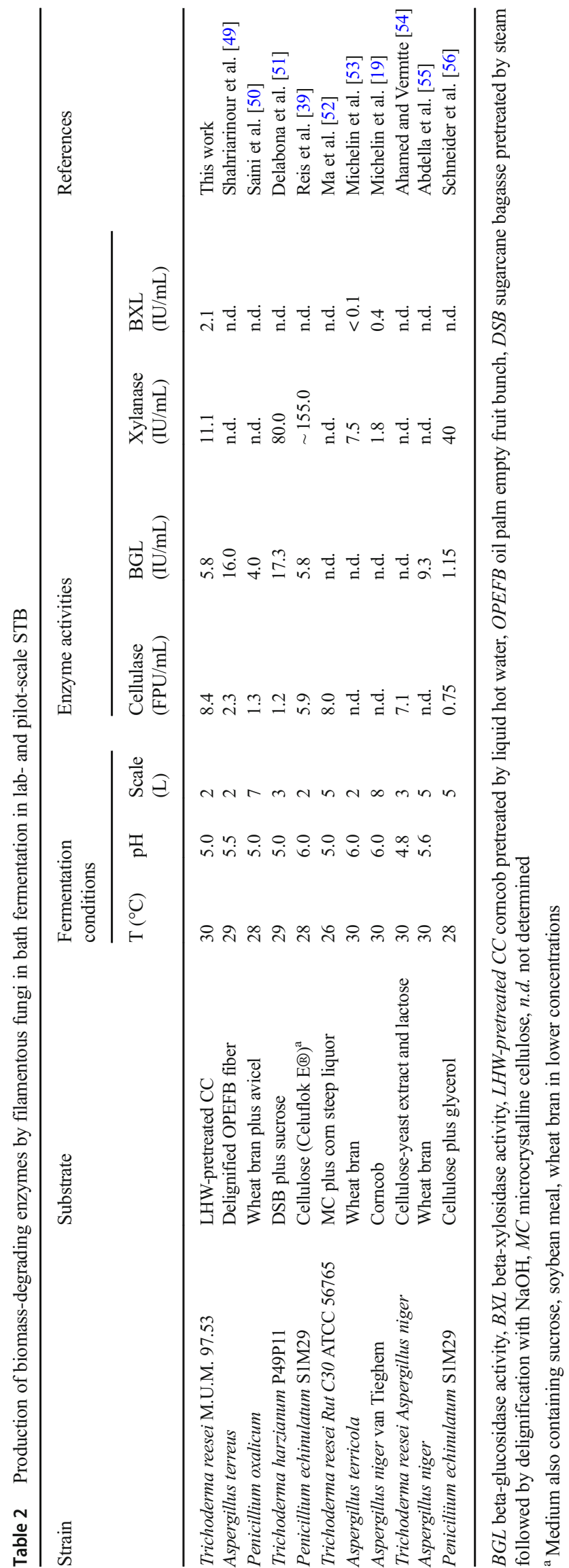

$\beta$-xylosidase) at $150 \mathrm{rpm}$ and $4 \mathrm{vvm}$ when compared to $150 \mathrm{rpm}$ and $2 \mathrm{vvm}$ can be related with the DO deprivation in the last condition. At lower aeration, the fermenter may suffer $\mathrm{O}_{2}$ depletion due to poor mixing of its content and thus the movement of fungal biomass may be hampered [44]. It is important highlight that the highest $\beta$-glucosidase levels were achieved in the end of the fermentation, when the DO concentration was higher than $90 \%$ of saturation.

Figure 3e shows that DO concentration presented a similar behavior for all conditions studied, i.e., DO concentration was maintained above $50 \%$ of saturation, with exception of the conditions of $150 \mathrm{rpm}$ and $2 \mathrm{vvm}$, where DO concentration fell down to zero after 1 day of fermentation. This drop in DO concentration at the beginning of fermentation can be attributed to an increase in oxygen consumption in the exponential phase of the fungal growth due to the fast increase in cell concentration in the first hours of fermentation [19, 42].

It is also known that the microbial physiology of filamentous fungal cells is significantly influenced by the DO concentration in suspended cultures, and it has been suggested that the critical DO concentration for fungal cells in culture should be greater than around $20 \%$ of the saturation DO value [ 45 , 46]. In this study, no effort was made to maintain the DO above $20 \%$ in order to investigate the effect of DO on enzyme production by the fungus $T$. reesei MUM 97.53. The results suggested that, as already reported by Michelin et al. [19] and Ghoshal et al. [44], the oxygen transfer rate from the gas phase to the liquid phase was lower than the oxygen uptake rate of the microorganism in the liquid phase, i.e., the combination of the studied agitation $(150 \mathrm{rpm})$ and aeration $(2 \mathrm{vvm})$ rates probably was not enough to maintain the oxygen supply at sufficient levels to cover the demand of the microorganism during the exponential growth phase. On the other hand, Reis et al. [39] varied the stirring and air flow rates in order to maintain a satisfactory concentration of dissolved oxygen in the culture media (oxygen level above $30 \%$ of air saturation) and avoid depletion of oxygen on culture medium.

As observed for $\mathrm{DO}$ concentration, the $\mathrm{pH}$ of the medium decreased in the beginning of the fermentation (Fig. 3f) but increased again after that. Fontana et al. [42] observed a minimum $\mathrm{pH}$ of 2.7 in a STB, reaching 5.10 at the end of the fermentation process by Aspergillus oryzae. This drop in $\mathrm{pH}$

Table $3 \quad k_{L} a$ values for the conditions used in the STR

\begin{tabular}{llll}
\hline Run & Agitation speed (rpm) & Airflow rate $(\mathrm{vvm})$ & $k_{L} a\left(\mathrm{~h}^{-1}\right)$ \\
\hline 1 & 150 & 2 & $16.41 \pm 1.46$ \\
2 & 150 & 4 & $32.50 \pm 3.49$ \\
3 & 250 & 2 & $18.47 \pm 2.33$ \\
4 & 250 & 4 & $31.21 \pm 0.38$
\end{tabular}

The values presented correspond to mean values of two replicate experiment 
Fig. 4 Production of cellulase, $\beta$ glucosidase, xylanase, and $\beta$ xylosidase in the stirred tank bioreactor at a $k_{L} a$ of $16.41 \mathrm{~h}^{-1}$ (black column), $18.47 \mathrm{~h}^{-1}$ (dark gray column), 31.21 (white column), and $32.50 \mathrm{~h}^{-1}$ (light gray column). The enzymatic activities correspond to the maximum activity of each enzyme

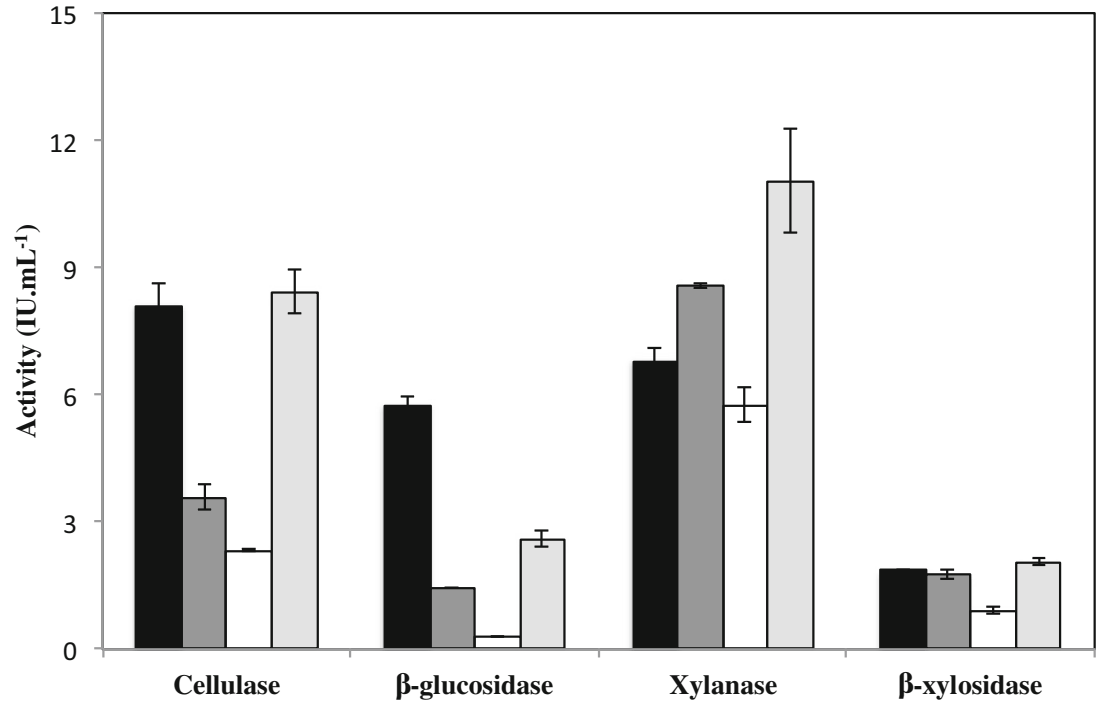

could be related to the production of acid metabolic by-products, as well as with the acetic acid released from hemicellulose during the degradation of the lignocellulosic substrate by the produced xylanases. Similar trend in $\mathrm{pH}$ decrease was also reported by Khanahmadi et al. [47] and Abdella et al. [48].

Table 2 presents the production of cellulases and xylanases by a few prominent microorganisms in laboratory and pilotscale bioreactors under batch submerged fermentation. The current work presented good levels of cellulase activities; however, better xylanase levels were reported by other authors (see Table 2). This can be related to the removal of a great part of the hemicellulose from lignocellulosic biomass, as well as to the fungus species used in the works.

\section{Relation of the Volumetric Oxygen Transfer Coefficient $\left(k_{L} a\right)$ with Enzyme Production}

$k_{L} a$ is the most significant parameter to measure transfer phenomena in a bioreactor, including oxygen transfer. Those are affected by many factors, including agitation speed and/or airflow rate [19]. Generally, the increase of $k_{L} a$ values is achieved by increasing agitation or airflow values; however, this practice is limited to a certain extent due to high shear rate, excessive foaming, and increased process costs. Thus, increasing these variables beyond a critical value decreases both mass transfer efficiency as well as microbial activity [23].

The influence of aeration and agitation rates on $k_{L} a$ was evaluated under the studied conditions. Results presented on Table 3 show that aeration rate was the most important variable to improve oxygen transfer, while $k_{L} a$ was less sensitive to the increment of the agitation speed. Mixing is very crucial for maximum productivity in microbial fermentation, and it could be achieved through agitation and aeration. But, agitation at higher stirring speeds may cause vortex formation, as well as free cell disruption in the reactor by forces, which may result in poor mass transfer (oxygen/substrate). Therefore, it is important to provide optimum combination of agitation and aeration in free cell batch bioreactor process [43]. Mass transfer achieves a critical value at $250 \mathrm{rpm}$ and $4 \mathrm{vvm}$, where no improvement in mass transfer was observed with increasing agitation. This condition corresponded to the lowest enzymatic activities (Fig. 4). This drop in enzyme activity can be related to the negative impact of shear stress caused by the STB mixing turbine on mycelia [19].

The highest cellulase, xylanase, and $\beta$-xylosidase activities were observed for a $k_{L} a$ value of $32.50 \mathrm{~h}^{-1}$, while the highest $\beta$ glucosidase activity was verified at $16.41 \mathrm{~h}^{-1}$. These $k_{L} a$ values were obtained for the lower agitation speed $(150 \mathrm{rpm})$, showing the high sensitivity of the fungus to the shear stress (Fig. 4).

Zhou et al. [24] studied the effects of agitation and aeration on the production of a glycoprotein based on $k_{L} a$ and verified that $k_{L} a$ values increased as agitation speed and aeration rate increased in the bioreactor. At agitation speeds of 150 to $300 \mathrm{rpm}$ and an aeration rate of $1 \mathrm{vvm}$, they reported similar $k_{L} a$ values (14.53-32.82 $\mathrm{h}^{-1}$ ) to this work. However, although $k_{L} a$ values increased with agitation and aeration rates, they verified that too high $k_{L} a$ had a negative effect on glycoprotein production due to the high shear force caused by high agitation rate, which could destroy the structure of cell and mycelium, and affect the biosynthesis of glycoprotein. The harmful effect of the shear forces due to the higher agitation rate has been reported to cause a reduced enzyme production in some filamentous fungi by other authors [19, 20, 43, 47].

\section{Conclusions}

The findings of this work demonstrate the potential of liquid hot water pretreatment to improve the production of biomassdegrading enzymes using pretreated biomass as fermentation 
substrate, as well as the influence of the aeration rate and agitation speed on $k_{L} a$ and enzyme production. Results suggest that variables such as aeration and agitation are the key when defining a strategy to optimize the production of fungal enzymes, once aeration supplies the necessary oxygen for cell growth and agitation could assure an efficient mixing of oxygen, heat, and nutrients, as well as disperse the air into smaller bubbles to improve the gas-liquid contact area. Besides, $k_{L} a$ could be improved by increasing aeration and/or agitation but with technical and physiological limitations, since the very high agitation speed may lead to the reduction of enzymatic activity due to shear stress.

Acknowledgments The authors thank Professor Dr. Nelson Lima from MUM (Micoteca da Universidade do Minho, Portugal) by the fungal strain.

Funding Information Michele Michelin is a recipient of a FCT fellowship (SFRH/BPD/100786/2014). This study was supported by the Portuguese Foundation for Science and Technology (FCT) under the scope of the strategic funding of UID/BIO/04469/2013 unit and BioTecNorte operation (NORTE-01-0145-FEDER-000004) funded by the European Regional Development Fund under the scope of Norte2020 - Programa Operacional Regional do Norte.

\section{References}

1. Pino MS, Rodríguez-Jasso RM, Michelin M, Flores-Gallegos AC, Morales-Rodriguez R, Teixeira JA, Ruiz HA (2018) Bioreactor design for enzymatic hydrolysis of biomass under the biorefinery concept - review. Chem Eng J 347:119-136

2. Johnson E (2016) Integrated enzyme production lowers the cost of cellulosic ethanol. Biofuels Bioprod Biorefin 10:164-174

3. Lee EJ, Lee BH, Kim BK, Lee JW (2013) Enhanced production of carboxymethylcellulase of a marine microorganism Bacillus subtilis subsp. subtilis A-53 in a pilot-scaled bioreactor by a recombinant Escherichia coli JM109/A-53 from rice bran. Mol Biol Rep 40:3609-3621

4. Cunha FM, Kreke T, Badino AC, Farinas CS, Ximenes E, Ladisch MR (2014) Liquefaction of sugarcane bagasse for enzyme production. Bioresour Technol 172:249-252

5. Yang P, Zhang H, Cao L, Zheng Z, Jiang S (2016) Construction of Aspergillus niger integrated with cellulase gene from Ampullaria gigas Spix for improved enzyme production and saccharification of alkaline-pretreated rice straw. 3 Biotech 6(2):236

6. Ravindran R, Jaiswal AK (2016) Microbial enzyme production using lignocellulosic food industry wastes as feedstock: a review. Bioengineering 3(30): 1-22

7. Biswas R, Persad A, Bisaria VS (2014) Production of cellulolytic enzymes. In: Bisaria VS, Kondo A (eds) Bioprocessing of renewable resources to commodity bioproducts. Wiley, pp 105-132

8. Michelin M, Ruiz HA, Silva DP, Ruzene DS, Teixeira JA, Polizeli MLTM (2014) Cellulose from lignocellulosic waste. In: Ramawat KG, Mérillon J-M (eds) Polysaccharides: bioactivity and biotechnology. Springer, pp 475-512

9. Menezes DB, Brazil OAV, Romanholo-Ferreira LF, Polizeli MLTM, Ruzene DS, Silva DP, Costa LP, Hernández-Macedo ML (2017) Prospecting fungal ligninases using corncob lignocellulosic fractions. Cellulose 24:4355-4365
10. Dashtban M, Schraft H, Qin WS (2009) Fungal bioconversion of lignocellulosic residues - opportunities \& perspectives. Int J Biol Sci 5:578-595

11. Zhang L, Liu Y, Niu X, Liu Y, Liao W (2012) Effects of acid and alkali treated lignocellulosic materials on cellulase/xylanase production by Trichoderma reesei Rut C-30 and corresponding enzymatic hydrolysis. Biomass Bioenergy 37:16-24

12. Michelin M, Romaní A, Salgado JM, Domingues L, Teixeira JA (2017) Production of hemicellulases, xylitol, and furan from hemicellulosic hydrolysates using hydrothermal pretreatment. In: Ruiz HA, Thomsen MH, Trajano HL (eds) Hydrothermal processing in biorefineries - production of bioethanol and high addedvalue compounds of second and third generation biomass. Springer, pp 285-316

13. Lo CM, Zhang Q, Callow NV, Ju LK (2010) Cellulase production by continuous culture of Trichoderma reesei Rut C30 using acid hydrolysate prepared to retain more oligosaccharides for induction. Bioresour Technol 101(2):717-723

14. Bakri Y, Akeed Y, Thonart P (2012) Comparison between continuous and batch processing to produce xylanase by Penicillium canescens 10-10c. Braz J Chem Eng 29:441-447

15. Michelin M, Polizeli MLTM, Ruzene DS, Silva DP, Vicente AA, Jorge JA, Terenzi HF, Teixeira JA (2012a) Xylanase and $\beta$ xylosidase production by Aspergillus ochraceus: new perspectives for the application of wheat straw autohydrolysis liquor. Appl Biochem Biotechnol 166:336-347

16. Michelin M, Polizeli MLTM, Ruzene DS, Silva DP, Ruiz HA, Vicente AA, Jorge JA, Terenzi HF, Teixeira JA (2012b) Production of xylanase and $\beta$-xylosidase from autohydrolysis liquor of corncob using two fungal strains. Bioprocess Biosyst Eng 35:1185-1192

17. Vitcosque GL, Fonseca RF, Rodríguez-Zúñiga UF, Bertucci Neto V, Couri S, Farinas CS (2012) Production of biomass-degrading multienzyme complexes under solid-state fermentation of soybean meal using a bioreactor. Enzyme Res 2012:1-9

18. Singh S, du Preez JC, Pillay B, Prior BA (2000) The production of hemicellulases by Thermomyces lanuginosus strain SSBP: influence of agitation and dissolved oxygen tension. Appl Microbiol Biotechnol 54:698-704

19. Michelin M, Mota AMO, Polizeli MLTM, Silva DP, Vicente AA, Teixeira JA (2013) Influence of volumetric oxygen transfer coefficient $\left(k_{L} a\right)$ on xylanases batch production by Aspergillus niger van Tieghem in stirred tank and internal-loop airlift bioreactors. Biochem Eng J 80:19-26

20. Techapun C, Poosaran N, Watanabe M, Sasaki K (2003) Optimization of aeration and agitation rates to improve cellulasefree xylanase production by thermotolerant Streptomyces $s p$. Ab 106 and repeated fed-batch cultivation using agricultural waste. J Biosci Bioeng 95(3):298-301

21. Potumarthi R, Ch S, Jetty A (2007) Alkaline protease production by submerged fermentation in stirred tank reactor using Bacillus licheniformis NCIM-2042: effect of aeration and agitation regimes. Biochem Eng J 34:185-192

22. Fenice M, Barghini P, Selbmann L, Federici F (2012) Combined effects of agitation and aeration on the chitinolytic enzymes production by the Antarctic fungus Lecanicillium muscarium CCFEE 5003. Microb Cell Factories 11:12

23. Dixit P, Mehta A, Gahlawat G, Prasad GS, Choudhury AR (2015) Understanding the effect of interaction among aeration, agitation and impeller positions on mass transfer during pullulan fermentation by Aureobasidium pullulans. RSC Adv 5:38984-38994

24. Zhou Y, Han L-R, He H-W, Sang B, Yu D-L, Feng J-T, Zhang X (2018) Effects of agitation, aeration and temperature on production of a novel glycoprotein GP-1 by Streptomyces kanasenisi ZX01 and scale-up based on volumetric oxygen transfer coefficient. Molecules 23(125):1-14 
25. Sluiter A, Hames B, Ruiz R, Scarlata C, Sluiter J, Templeton D, Crocker D (2008) Determination of structural carbohydrates and lignin in biomass. NREL - LAP Technical Report NREL/TP-51042618

26. Mandels M, Weber J (1969) The production of cellulases. Adv Chem Ser 95:391-414

27. Miller GH (1959) Use of dinitrosalicylic acid reagent for determination of reducing sugar. Anal Chem 31:426-429

28. Lima MS, Damasio ARL, Crnkovic PM, Pinto MR, da Silva AM, da Silva JCR, Segato F, de Lucas RC, Jorge JA, Polizeli MLTM (2016) Co-cultivation of Aspergillus nidulans recombinant strains produces an enzymatic cocktail as alternative to alkaline sugarcane bagasse pretreatment. Front Microbiol 7:583

29. Ferreira A, Pereira G, Teixeira JA, Rocha F (2012) Statistical tool combined with image analysis to characterize hydrodynamics and mass transfer in a bubble column. Chem Eng J 180:216-228

30. Michelin M, Ruiz HA, Polizeli MLTM, Teixeira JA (2018) Multistep approach to add value to corncob: production of biomass degrading enzymes, lignin and fermentable sugars. Bioresour Technol 247:582-590

31. Cunha FM, Esperança MN, Florencio C, Vasconcellos VM, Farinas CS, Badino AC (2015) Three-phasic fermentation systems for enzyme production with sugarcane bagasse in stirred tank bioreactors: effects of operational variables and cultivation method. Biochem Eng J 97:32-39

32. Gottschalk LMF, Oliveira RA, Bon EPS (2010) Cellulases, xylanases, $\beta$-glucosidase and ferulic acid esterase produced by Trichoderma and Aspergillus act synergistically in the hydrolysis of sugarcane bagasse. Biochem Eng J 51:72-78

33. Tiwari P, Misra BN, Sangwan NS (2013) $\beta$-Glucosidases from the fungus Trichoderma: an efficient cellulase machinery in biotechnological applications - review. Biomed Res Int 2013:1-10

34. Khonzue P, Laothanachareon T, Rattanaphan N, Tinnasulanon P, Apawasin S, Paemanee A, Ruanglek V, Tanapongpipat S, Champreda V, Eurwilaichitr L (2011) Optimization of xylanase production from Aspergillus niger for biobleaching of eucalyptus pulp. Biosci Biotechnol Biochem 75(6):29-34

35. Guimarães NCA, Sorgatto M, Peixoto-Nogueira SC, Betini JHA, Zanoelo FF, Marques MR, Polizeli MLTM, Giannesi GC (2013) Bioprocess and biotechnology: effect of xylanase from Aspergillus niger and Aspergillus flavus on pulp biobleaching and enzyme production using agroindustrial residues as substract. SpringerPlus 2: 380

36. Ajijolakewu AK, Leh CP, Abdullah WNW, Lee CK (2017) Optimization of production conditions for xylanase production by newly isolated strain Aspergillus niger through solid state fermentation of oil palm empty fruit bunches. Biocatal Agric Biotechnol 11:239-247

37. Michelin M, Teixeira JA (2016) Liquid hot water pretreatment of multi feedstocks and enzymatic hydrolysis of solids obtained thereof. Bioresour Technol 216:862-869

38. Kumar R, Singh S, Singh OV (2008) Bioconversion of lignocellulosic biomass: biochemical and molecular perspectives. J Ind Microbiol Biotechnol 35:377-391

39. Reis L, Fontana RC, Delabona PS, Lima DJS, Camassola M, Pradella JGC, Dillon AJP (2013) Increased production of cellulases and xylanases by Penicillium echinulatum S1M29 in batch and fedbatch culture. Bioresour Technol 146:597-603

40. Li P, Liang H, Lin W-T, Feng F, Luo L (2015) Microbiota dynamics associated with environmental conditions and potential roles of cellulolytic communities in traditional chinese cereal starter solid-state fermentation. Appl Environ Microbiol 81(15):5144-5156
41. Patel N, Choy V, Malouf P, Thibault J (2009) Growth of Trichoderma reesei RUTC30 in stirred tank and reciprocating plate bioreactors. Process Biochem 44:1164-1171

42. Fontana RC, Silveira MM (2012) Production of polygalacturonases by Aspergillus oryzae in stirred tank and internal- and external-loop airlift reactors. Bioresour Technol 123:157-163

43. Bakri Y, Mekaeel A, Koreih A (2011) Influence of agitation speeds and aeration rates on the xylanase activity of Aspergillus niger SS7. Braz Arch Biol Technol 54(4):659-664

44. Ghoshal G, Banerjee UC, Shivhare US (2014) Xylanase production by Penicillium citrinum in laboratory-scale stirred tank reactor. Chem Biochem Eng Q 28(3):399-408

45. Braun S, Vecht-Lifshitz SE (1991) Mycelial morphology and metabolite production. Trends Biotechnol 9:63-68

46. Shin W-S, Lee D, Kim S, Jeong Y-S, Chun G-T (2013) Application of scale-up criterion of constant oxygen mass transfer coefficient $\left(\mathrm{k}_{\mathrm{L}}\right.$ a) for production of itaconic acid in a $50 \mathrm{~L}$ pilot-scale fermentor by fungal cells of Aspergillus terreus. J Microbiol Biotechnol 23(10):1445-1453

47. Khanahmadi M, Arezi I, Amiri M-S, Miranzadeh M (2018) Bioprocessing of agro-industrial residues for optimization of xylanase production by solid- state fermentation in flask and tray bioreactor. Biocatal Agric Biotechnol 13:272-282

48. Abdella A, Mazeed TE-S, El-Baz AF, Yang S-T (2016) Production of !-glucosidase from wheat bran and glycerol by Aspergillus niger in stirred tank and rotating fibrous bed bioreactors. Process Biochem 51:1331-1337

49. Shahriarinour M, Ramanan RN, Wahab MNA, Mohamad R, Mustafa S, Ariff AB (2011) Improved cellulase production by Aspergillus terreus using oil palm empty fruit bunch fibre as substrate in a stirred tank bioreactor through optimization of the fermentation conditions. BioResources 6(3):2663-2675

50. Saini R, Saini JK, Adsul M, Patel AK, Mathur A, Tuli D, Singhania RR (2015) Enhanced cellulase production by Penicillium oxalicum for bio-ethanol application. Bioresour Technol 188:240-246

51. Delabona PS, Farinas CS, Silva MR, Azzoni SF, Pradella JGC (2012) Use of a new Trichoderma harzianum strain isolated from the Amazon rainforest with pretreated sugar cane bagasse for onsite cellulase production. Bioresour Technol 107:517-521

52. Ma L, Li C, Yang Z, Jia W, Zhang D, Chen S (2013) Kinetic studies on batch cultivation of Trichoderma reesei and application to enhance cellulase production by fed-batch fermentation. J Biotechnol 166:192-197

53. Michelin M, Polizeli MLTM, Silva DP, Ruzene DS, Vicente AA Jorge JA, Terenzi HF, Teixeira JA (2011) Production of xylanolytic enzymes by Aspergillus terricola in stirred tank and airlift tower loop bioreactors. J Ind Microbiol Biotechnol 38:1979-1984

54. Ahamed A, Vermette $P$ (2008) Enhanced enzyme production from mixed cultures of Trichoderma reesei RUT-C30 and Aspergillus niger LMA grown as fed batch in a stirred tank bioreactor. Biochem Eng J 42:41-46

55. Abdella A, Mazeed TE-S, Yang S-T, El-Baz AF (2014) Production of $\beta$-glucosidase by Aspergillus niger on wheat bran and glycerol in submerged culture: factorial experimental design and process optimization. Curr Biotechnol 3:197-206

56. Schneider WDH, Reis L, Fontana RC, Dillon AJP, Camassola M (2018) Exploring strategies for the use of glycerol in the production of cellulases and xylanases, and the use of these enzymes in the hydrolysis of lignocellulosic biomass. Ind Crop Prod 122:114-118

Publisher's Note Springer Nature remains neutral with regard to jurisdictional claims in published maps and institutional affiliations. 